\title{
Molecular studies on ancient M. tuberculosis and M. leprae: methods of pathogen and host DNA analysis
}

\author{
H. W. Witas ${ }^{1}$ • H. D. Donoghue ${ }^{2}$ D. Kubiak ${ }^{1}$ - M. Lewandowska ${ }^{1}$. \\ J. J. Gladykowska-Rzeczycka ${ }^{3}$
}

Received: 26 March 2015 / Accepted: 9 June 2015 / Published online: 26 July 2015

(C) The Author(s) 2015. This article is published with open access at Springerlink.com

\begin{abstract}
Humans have evolved alongside infectious diseases for millennia. Despite the efforts to reduce their incidence, infectious diseases still pose a tremendous threat to the world population. Fast development of molecular techniques and increasing risk of new epidemics have resulted in several studies that look to the past in order to investigate the origin and evolution of infectious diseases. Tuberculosis and leprosy have become frequent targets of such studies, owing to the persistence of their molecular biomarkers in ancient material and the characteristic skeletal lesions each disease may cause. This review examines the molecular methods used to screen for the presence of M. tuberculosis and M. leprae ancient DNA (aDNA) and their differentiation in ancient human remains. Examples of recent studies, mainly from Europe, that employ the newest techniques of molecular analysis are also described. Moreover, we present a specific approach based on assessing the likely immunological profile of historic populations, in order to further elucidate the influence of M. tuberculosis and M. leprae on historical human populations.
\end{abstract}

H. W. Witas

henryk.witas@umed.lodz.pl

1 Department of Molecular Biology, Medical University of Łódź, Łódź, Poland

2 Division of Infection and Immunity, University College London, London, UK

3 Retired professor, Marusarzówny, Gdańsk, Poland

\section{Introduction}

Infectious diseases such as tuberculosis, plague, leprosy and cholera have accompanied humans since the dawn of our history. The past is marked by epidemics and pandemics that have influenced all aspects of human life. Scientific discoveries and significant development of techniques of molecular biology in recent years have caused increasing interest in investigating the origins and history of infectious diseases and their agents. Studying ancient diseases is essential for understanding microbial evolution, spread, and confirmation of epidemics and pandemics. Tuberculosis and leprosy are among the diseases that arouse the greatest interest in paleopathologists, as they may leave characteristic lesions on the bones that suggest a diagnosis based on bone morphology. In osteoarticular tuberculosis, skeletal lesions are most often found in the thoracic and lumbar vertebrae, as well as hip and knee joints. Tuberculosis can also attack the epiphysis and metaphysis of the long bones (Fig. 1a-c). Lesions on the internal surface of ribs are another indicator of possible skeletal tuberculosis but do not provide firm identification $[1,2]$. Changes considered as indicative of leprosy include the rhinomaxillary syndrome (Facies leprosa) (Fig. 1d) and lesions of the hand, foot, tibia and fibula (Fig. 1e). New bone formation in the peritoneum of tibia and fibula alone are not accepted as criteria for leprosy diagnosis due to the fact that a number of conditions can cause those changes $[2,3]$.

Both tuberculosis and leprosy are caused by mycobacteria, which have characteristic, lipid-rich thick cell walls that are less susceptible to degradation [5] and can be detected directly, without amplification [6, 7]. These lipid biomarkers are totally distinct from anything found in mammalian tissue and are specific for members of the Mycobacterium tuberculosis complex (MTBC) or M. leprae, so enable independent identification of these pathogens in ancient material at 
Fig. 1 Lesions typical of tuberculosis: a defects of proximal epiphysis of the tibia seen from above, $\mathbf{b}$ distorted distal end of the femur (Sypniewo, northeast Poland), c changes of the distal end of the left forearm and carpus (Ołbin in Wrocław, southwest Poland); lesions typical of leprosy: $\mathbf{d}$ defects in the palate, e fusion of the Lisfranc joint and atrophy of the first metatarsal bone (Suraż, northeast Poland) [4]
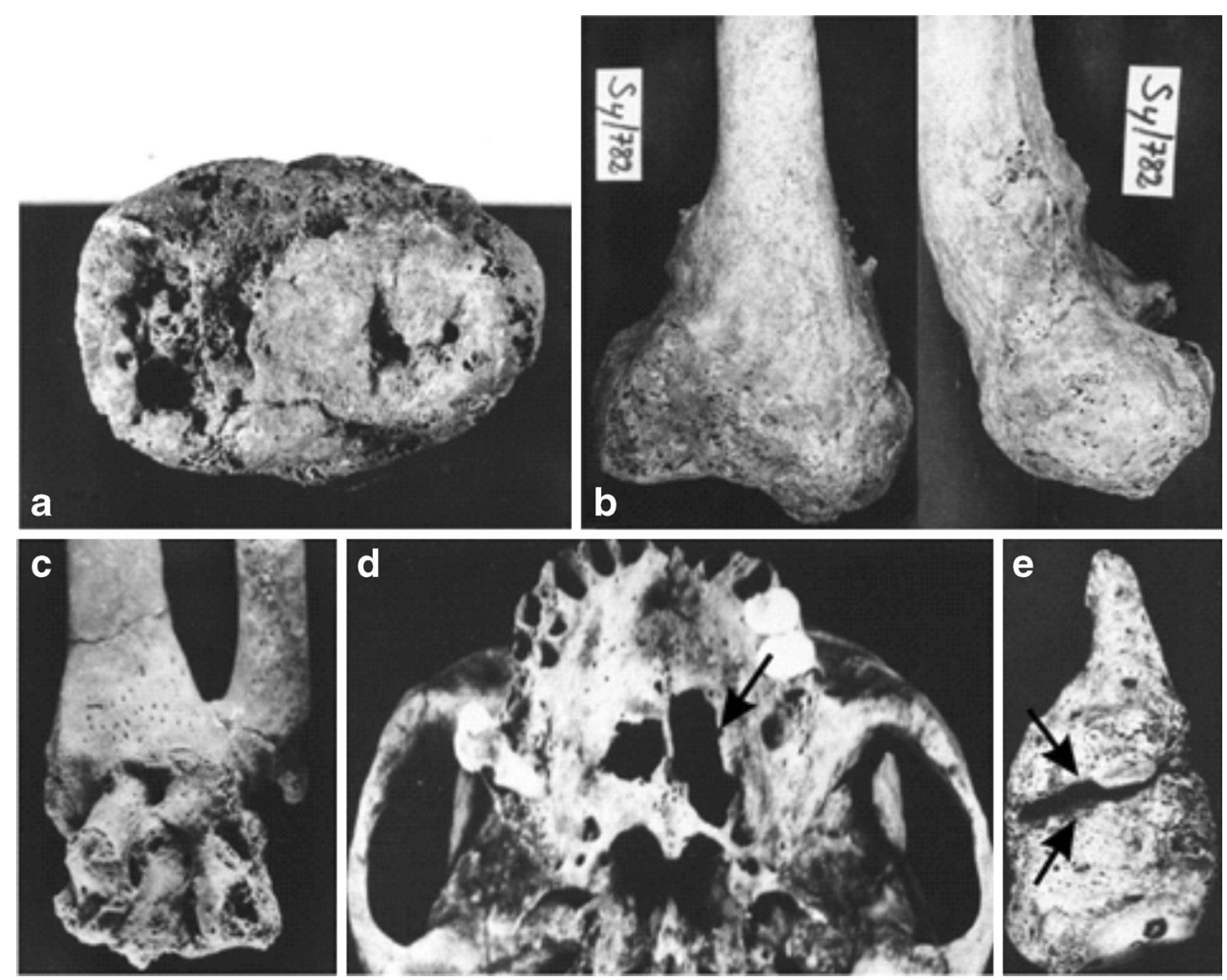

the molecular level. Molecular markers not only allow the verification of paleopathological diagnoses but also enable individuals with ambiguous or no visible lesions to be screened for the presence of bacterial biomolecular markers, since, in the majority of tuberculosis and leprosy cases, there are no visible bone changes $[8,9]$.

Tuberculosis and leprosy are fatal diseases that still cause deaths in both developed and developing countries. It is a curable and preventable disease that most often affects lungs, caused by members of a group of closely related bacterial species, which comprise the MTBC. It is the greatest killer worldwide due to a single infectious agent. Data obtained from 202 countries and territories show that, in 2013, 9.0 million people were infected with $M$. tuberculosis, 1.5 million died because of tuberculosis, while about one-third of the world's population has latent tuberculosis [10]. Leprosy is a curable, chronic disease caused by Mycobacterium leprae. This disease mainly affects skin, peripheral nerves, mucosa of the upper respiratory tract and eyes. According to official data from 102 countries, 215,656 new cases of leprosy were reported in 2013 [11] and it is still the greatest cause of infection-related disability in the world.

The earliest known paleopathological evidence of human tuberculosis was found in ancient Syria at around the time (8800-7600 BC) of animal domestication [12]. Before this study, the earliest evidence was from two Neolithic individuals (7000 BC) in the Eastern Mediterranean [13]. Other ancient cases of tuberculosis described in the literature include a 5400-4800 BC case from central Germany [14], a 5000 BC case from Hungary [6] and a $4000 \mathrm{BC}$ case from Italy [15, 16]. The first molecular studies of ancient infectious diseases used the method of collecting samples and testing for the presence of MTBC ancient DNA (aDNA) described by Spigelman and Lemma [17]. In 1994, the first report of tuberculosis based on tissue from a pre-Columbian Peruvian mummy was published, including confirmatory aDNA cloning and sequencing [18]. The earliest known paleopathological evidence of leprosy came from India from the post-urban phase of the Indus Age [19]. A number of other ancient cases of leprosy have been described in the literature, including a 4th-3rd century BC case from Bologna, northeastern Italy [20], a 4th century BC-3rd century AD case from Thailand [21] and a 3rd century BC case from Britain [22]. The first molecular evidence of M. leprae was published in 1994 [23, 24] and the oldest sample confirmed by polymerase chain reaction (PCR) was from the 1 st century $\mathrm{AD}[25]$. The present article is a review of methods used for the identification and differentiation of the MTBC and $M$. leprae DNA in ancient human remains. Furthermore, we present a number of tuberculosis and leprosy cases, mainly from Europe, in samples recently excavated from archaeological sites and those housed in museum collections that have been subjected to molecular analysis. Finally, we propose further approaches for assessing the possible presence of bacteria and their influence on ancient humans, mainly 
by estimation of the immunological profiles of historic populations.

\section{Methods of molecular identification and differentiation of M. tuberculosis and M. leprae}

\section{Properties of aDNA}

Spontaneous hydrolysis and oxidation are examples of the most commonly found damage that cause post mortem instability of nucleic acids. DNA decay typically demonstrates baseless sites, double- and single-strand breaks, miscoding lesions and cross-links [26-29], although the relative rates of different kinds of aDNA damage and their mode of accumulation vary between specimens under different environmental conditions [30]. Since it is almost impossible to retrieve long amplification products of aDNA, researchers focus on short sequences, around 100-200 base pairs (bp), and repetitive regions. Real-time PCR, based on the incorporation of fluorescent markers into double-stranded DNA, is especially useful in this kind of research because of the ability to target shorter regions that can be visualised on screen instead of on a gel. Genomic deletions can be examined by PCR followed by gel electrophoresis. Detection of single nucleotide polymorphisms (SNPs) by PCR-restriction fragment length polymorphism (PCR-RFLP) analysis is based on sequencing of the PCR product or its digestion with a restriction enzyme and subsequent gel electrophoresis. The problems arising from degradation and contamination of the samples are much reduced in methodology such as next-generation sequencing (NGS) [31] or whole-genome sequencing (WGS) [32]. In NGS, selective enrichment of target DNA can be achieved by the use of microarrays or bead suspensions that are able to bind specific target sequences. An alternative approach in WGS is 'shotgun' sequencing, where every DNA fragment is tagged and sequenced. Thereafter, high-throughput sequencing and bioinformatic analysis is performed $[33,34]$.

\section{Molecular identification and differentiation of the MTBC and M. tuberculosis}

The MTBC consists of a group of very closely related species, including M. tuberculosis, M. africanum, M. bovis, M. microti, M. pinnipedii and $M$. canettii $[35,36]$ that cause infections in humans and animals. Identification of the MTBC at the species level, as well as differentiation of M. tuberculosis genotypes derived from skeletal samples, may be performed using the molecular methods described below. In the MTBC, there are specific regions of the repetitive element IS6110 that can identify these pathogenic lineages. In human $M$. tuberculosis, the number of copies of IS6110 varies between strains, from 0 in rare strains from Southeast Asia to 24 copies/cell, while in other members of the MTBC, there is only one copy of this element per cell [37]. The specific IS6110 primers have been used frequently as a marker of the presence of MTBC DNA but it has long been known that different regions of this repetitive element have been detected in mycobacteria other than tuberculosis [38]. The repetitive element IS1081 is also used to detect DNA from the MTBC and, as there are normally six copies per cell, it has been used for quantitative analysis and for the detection of M. bovis [39]. Other examples used for the detection of the MTBC include specific sites in the RNA polymerase beta gene $(r p o B)$ and $19 \mathrm{kDa}$ antigen gene [40-42]. Evolutionary 'modern' and 'ancient' strains of M. tuberculosis can be distinguished by analysis of the M. tuberculosis-specific D1 deletion site (Fig. 2). Loss of the $\mathrm{TbD} 1$ region is common in strains from all three major groups of M. tuberculosis described by Sreevatsan et al. [43], in contrast to all strains of $M$. bovis and in a part of the early group 1 lineage of M. tuberculosis [44].

Since the entire genome of M. tuberculosis and M. bovis have been sequenced, there is a wide choice of genetic sites that can be used to distinguish between these species. For example, M. tuberculosis and M. bovis can be distinguished from $M$. bovis based on the deletion region RD2 (now known as RD7) that is absent in M. bovis [45, 46]. Spoligotyping (spacer oligonucleotide typing) is based on the variation of the direct-repeat (DR) locus found in the members of the MTBC that enables the differentiation of the members of the MTBC and identification of M. tuberculosis strains. This region contains multiple, well-conserved $36 \mathrm{bp}$ (DRs) interspersed with non-repetitive spacers of 34 to $41 \mathrm{bp}$. Members of the MTBC and strains of M. tuberculosis vary in the number of DRs and in the absence or presence of particular spacers [47]. The spacer regions can be lost over time, so this method is suitable for investigating evolutionary aspects of human tuberculosis and has also been used to clarify the origin and transmission of this disease in different time periods and populations. The MTBC can be assigned to four genotypic groups, known as principal genetic groups (PCGs) (Table 1), based on the combination of polymorphisms at codons 463 and 203 of the $k a t G$ gene and codon 95 of the gyrA gene [43, 48].

Differentiation of the species of the MTBC can now be performed by typing based on synonymous SNPs that are functionally neutral, so can be used to distinguish between lineages, aided by the lack of horizontal gene transfer. Initially, SNP-based phylogenetic analysis of a global collection of M. tuberculosis isolates classified the MTBC into six phylogenetically distinct groups, called lineages or SNP cluster groups (SCGs), with a seventh group containing all M. bovis isolates [49]. Subsequently, this led to the recognition of seven phylogeographic lineages, each associated with specific human populations, with the animal lineages sometimes described as lineage 8 [50]. The results of WGS [50] as well as 
Fig. 2 Sequences in the TBD1 region received from strains of different geographic regions [45]
TbD1-region

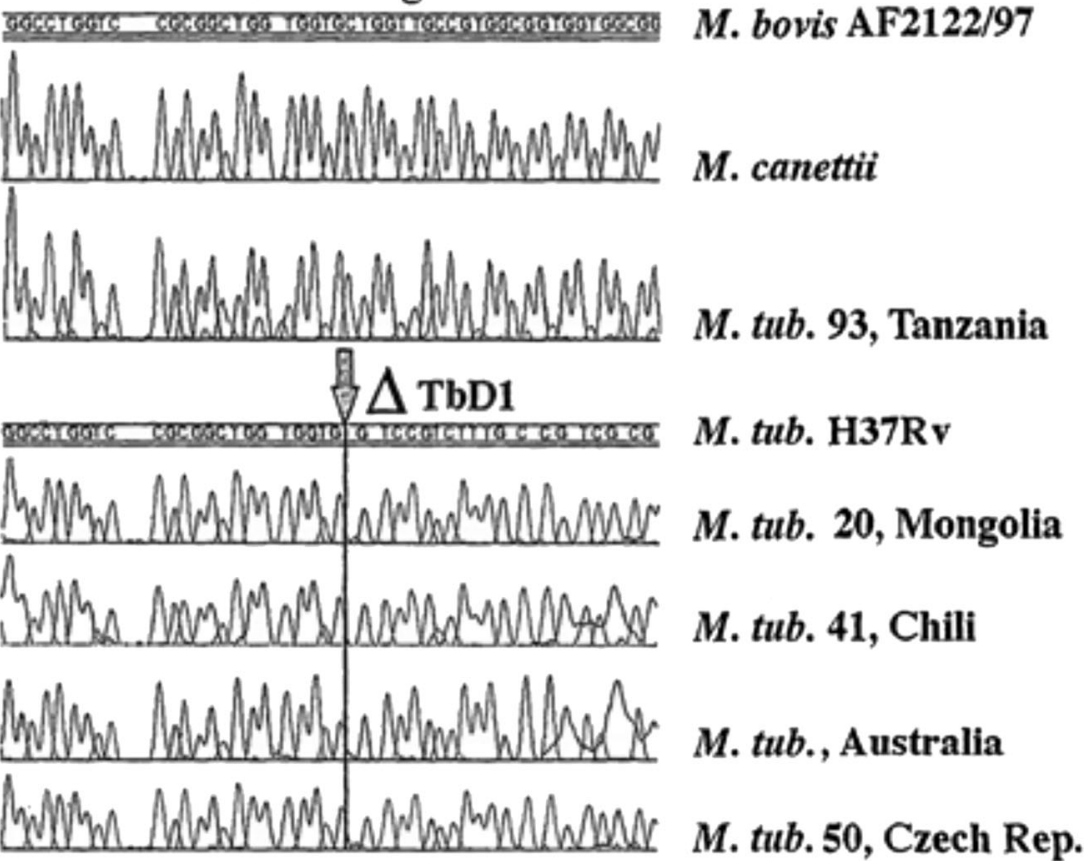

genotyping and selected sequencing, for example, large sequence polymorphisms (LSP) [51], suggest that each lineage is linked with a restricted geographical distribution. Lineage 1 occurs predominantly in the Philippines and Indian Ocean, lineage 2 in East Asia and lineage 3 in India as well as East Africa. In Europe and both Americas, lineage 4 is most likely to be observed, while lineage 5 occurs mostly in West Africa $[51,52]$. Lineage 7 has, so far, only been observed in Ethiopia and recent Ethiopian emigrants [53].

\section{Methods of molecular identification and differentiation of M. leprae}

All extant isolates of $M$. leprae are nearly indistinguishable, being derived from a single clone. The $M$. leprae genome has been shaped by reductive evolution and mass pseudogene formation that has moulded its 3.31-Mb genome. Molecular genotyping and sub-genotyping of $M$. leprae can be performed using methods based on SNPs. All isolates of $M$. leprae can be assigned to one of four SNP types determined by four combinations of three SNPs and 16 SNP subtypes (Table 2) based on SNPs and InDel repeat sequences $[54,55]$. Due to being an uncultivable obligate pathogen, isolates of $M$. leprae exhibit a strong relationship between their SNP subtypes and geographical locations that reflects patterns of early human migrations and trade routes, including the Silk Road that linked Europe and China. Thereby, SNP typing provides evidence for disease origins, dissemination and phylogeny [55].

Variable number tandem repeats (VNTR) typing is a method based on amplifying and sequencing of polymorphic microsatellite and minisatellite loci (short tandem repeat motif, STR) present in the M. leprae genome. Its usefulness in modern cases is well proven. The rpoT locus (ML1022c) was the first investigated VNTR locus in the $M$. leprae genome noncoding region. Two variants of a $6-b p$ tandem repeat,

Table 1 Genetic groups of the MTBC based on the mutations in the $k a t G$ and gyrA codons [43, 44, 48]

\begin{tabular}{|c|c|c|c|c|}
\hline \multirow[b]{2}{*}{ Gene codon } & \multicolumn{4}{|l|}{ Genetic group } \\
\hline & $1 \mathrm{~A}$ & $1 \mathrm{~B}$ & 2 & 3 \\
\hline$k a t G 463$ & CTG (Leu) & CTG (Leu) & CGG (Arg) & CGG (Arg) \\
\hline$k a t G 203$ & ACT (Thr) & ACE (Thr) & ACE $(\mathrm{Thr})$ & ACE $(\mathrm{Thr})$ \\
\hline gyrA 95 & AㄷC (Thr) & AㄷC (Thr) & ACEC (Thr) & A $\underline{G C}$ (Ser) \\
\hline Member of MTBC & $\begin{array}{l}\text { MTBC precursor } \\
\text { M. africanum group A, M. bovis, M. microti }\end{array}$ & $\begin{array}{c}\text { Ancestral } \\
\text { M. tuberculosis } \\
\text { M. africanum group B }\end{array}$ & M.tuberculosis & M.tuberculosis \\
\hline
\end{tabular}


Table 2 M. leprae SNP types by Monot et al. [54, 55]

\begin{tabular}{|c|c|c|c|c|}
\hline & \multicolumn{4}{|l|}{ SNP type } \\
\hline & 1 & 2 & 3 & 4 \\
\hline \multicolumn{5}{|l|}{ Position in genome } \\
\hline 14676 & $\mathrm{C}$ & $\mathrm{C}$ & $\mathrm{C}$ & $\mathrm{T}$ \\
\hline 1642875 & G & $\mathrm{T}$ & $\mathrm{T}$ & $\mathrm{T}$ \\
\hline 2935685 & A & A & $\mathrm{C}$ & $\mathrm{C}$ \\
\hline Subtypes & $\mathrm{A}, \mathrm{B}, \mathrm{C}, \mathrm{D}$ & $\mathrm{E}, \mathrm{F}, \mathrm{G}, \mathrm{H}$ & $\mathrm{I}, \mathrm{J}, \mathrm{K}, \mathrm{L}, \mathrm{M}$ & $\mathrm{N}, \mathrm{O}, \mathrm{P}$ \\
\hline Present occurrence & $\begin{array}{c}\text { Asia, the Pacific region, } \\
\text { East Africa }\end{array}$ & $\begin{array}{c}\text { Ethiopia, Malawi, Nepal/North India, } \\
\text { New Caledonia }\end{array}$ & $\begin{array}{c}\text { North Africa, } \\
\text { Americas }\end{array}$ & $\begin{array}{l}\text { West Africa, the } \\
\text { Caribbean region }\end{array}$ \\
\hline
\end{tabular}

composed of GACATC, have been reported, one of four and one of three tandem repeats [56]. TTC (AGA)20 locus (ML2344-ML2345) polymorphisms were also identified from the $M$. leprae genome sequence database. The number of repeats at each locus may vary among $M$. leprae strains, while most of the sequences in $M$. leprae seem to be conserved. Sequence analysis of the TTC repeat region in each of the $M$. leprae strains shows a variation of 10 to 37 repeats in the non-coding region. The most reliable explanation of the evolution of $M$. leprae strains with different numbers of TTC repeats is slippage or addition of one codon during replication $[57,58]$. Latterly, over 40 potential variable loci (33 microsatellites and 11 minisatellites) have been identified. Multiple loci variable number tandem repeats analysis (MLVA) can be used for investigating cases within a limited geographic area, to distinguish strains with the same SNP profiles.

\section{Use of molecular identification and differentiation in cases of ancient tuberculosis}

In the first paper published on the detection of ancient tuberculosis by molecular analysis, IS6110 was the target used [17, 18 ]. In a significant early study in 2002 , six cases dated to 7 th8 th century AD and eight cases dated to the 17 th century AD, from the collections housed at the Department of Anthropology at the University of Szeged, Hungary, were screened [59]. All examined individuals exhibited signs of infection on the bones. The presence of mycobacterial DNA was investigated by amplifying the gene encoding the $65 \mathrm{kDa}$ antigen, although this target is of doubtful use as it is found in all environmental mycobacteria. However, the presence of MTBC DNA was demonstrated by the amplification of a segment of the repetitive sequence IS6110. In several cases, the PCR product of IS6110 was treated with HaeIII to demonstrate MTBC typical digestion products. Direct sequencing was applied to establish the nucleotide sequences. The presence of mycobacterial DNA was confirmed in 13 cases, while IS6110 PCR was positive in eight cases [59].
In England, nine medieval human burials with signs of tuberculosis, from Wharram Percy, were screened [60]. PCR analysis of IS 6110 and rpoB enabled verification of the paleopathological diagnosis of tuberculosis. Conventional PCRs for $m t p-40, o x y R, p n c A$ and the RD7 deletion were performed to distinguish between $M$. tuberculosis and M. bovis. Since the skeletal lesions of brucellosis may resemble those of tuberculosis, PCR analysis for Brucella DNA was also undertaken with the use of the IS6501 multi-copy insertion element, variable among species of Brucella (5-35 repeats in the genome) but was negative. The results (Table 3 ) indicate that, in all nine tuberculosis cases from Wharram Percy, M. tuberculosis DNA rather than $M$. bovis DNA was present. Spoligotyping was also used here to detect and type members of the MTBC. This can also elucidate the origin and transmission of the pathogen in different time periods and populations [61].

In ancient Egypt, Zink and colleagues reported their analysis of bone and tissue samples from 85 Egyptian mummies, dated to 2050-500 BC, found in different tomb complexes of West Thebes, Upper Egypt [61]. Samples were screened for the presence of MTBC DNA, using IS6110 PCR. Those yielding positive results for $\mathrm{Mbov}, m t p-40$ and the $\operatorname{oxy} R$ regions were amplified to differentiate between $M$. tuberculosis and M. bovis. Furthermore, in those samples, spoligotyping was used for the subsequent analysis of $M$. tuberculosis DNA. IS6110 PCR confirmed the presence of MTBC DNA in 25 samples, although PCR methods to distinguish M. tuberculosis from $M$. bovis gave inconclusive results, as summarised in Table 4. Although five modern samples were positive with the $M$. bovis-specific primers, only two ancient samples were successfully amplified for $m t p-40$. The $o x y R$ gene was detected in only three ancient samples.

During spoligotyping, due to the degradation of the aDNA, all blots were performed in triplicate. Reproducible patterns were obtained from 12 individuals and compared to those in the international spoligotyping database. Three isolates matched types 53, 393 and 291 from the database and are close or identical to the ubiquitous $M$. tuberculosis type 53. Type 53 represents one of the most common profiles. Five 
Table 3 Genotyping of nine medieval individuals with signs of tuberculosis from Wharram Percy [60]

\begin{tabular}{ccccccccc}
\hline & IS6110 & rpoB & $m$ tp-40 & oxyR & pncA & RD7 deletion & Spoligotyping & IS6501 \\
\hline Controls & & & & & & & & \\
EE003 & - & - & nd & nd & nd & nd & nd & nd \\
G304 & - & - & nd & nd & nd & nd & nd & nd \\
Samples & & & & & & & & \\
EE056 & + & + & + & - & nd & nd & - & - \\
G438 & + & + & + & $+(G)$ & nd & - & nd & - \\
G482 & + & + & + & $+(G)$ & nd & - & - & - \\
NA026 & + & + & - & $+(G)$ & nd & - & Mtb & - \\
NA046 & + & nd & - & $+(G)$ & nd & - & Mtb & - \\
NA112 & - & + & + & $+(G)$ & nd & nd & Mtb & - \\
NA197 & + & + & + & - & nd & - & - & - \\
SA013 & - & + & + & $+(G)$ & nd & - & - & - \\
WCO142 & + & + & + & - & nd & - & - & - \\
\hline
\end{tabular}

$-=$ no result $;+=$ positive result $;$ nd $=$ not determined

${ }^{\text {a }}$ Brucella-specific insertions (5-35 repeats in the genome) samples showed a pattern similar to that of M. africanum. Others were not found in the database, but all of them were related to the M. tuberculosis TbD1-deleted type, suggested by the lack of spacers 33 to 36 and the presence of spacers between position 39 to 45. Patterns suggestive for M. bovis were not found in any of the examined samples. This study is an early example of paleoepidemiology and was made possible by the excellent preservation of the skeletal material in Ancient Egypt [62, 63].

A remarkable collection of 263 naturally mummified bodies was discovered in an 18th century AD Hungarian crypt in
Vác, Hungary in 1994-1995. In many cases, there were archival records giving details of name, family connections, date of death and, occasionally, information on occupation or symptoms. Because of the local environmental conditions, the human remains were in an excellent state of preservation. In an initial study [64], 350 samples from 168 individuals were examined. A two-tube nested PCR of the IS6110 insertion sequence was used in the initial screening. Polymorphisms at codon 463 of $k a t G$ and codon 95 of gyr $A$ were assessed in order to place the strains into genotypic groups [43]. Methods specific for M. tuberculosis were positive in $55 \%$ of the
Table 4 Results of PCR-based differentiation between M. tuberculosis and M. bovis [62]

\begin{tabular}{|c|c|c|c|c|c|c|}
\hline & M.bovis & $m t p-40-1 / 2$ & $m t p-40-3 / 4$ & $\operatorname{oxy} R$ & IS6110 & Spoligotyping \\
\hline \multicolumn{7}{|l|}{ Modern control DNA } \\
\hline$M t b$ H37Rv $(10 \mathrm{ng} / \mu \mathrm{l})$ & + & + & + & + & + & $M t b$ \\
\hline 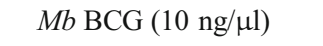 & + & + & + & + & + & $M b$ \\
\hline$M t b \mathrm{H} 37 \mathrm{Rv}(0.1 \mathrm{ng} / \mu \mathrm{l})$ & - & + & + & + & + & $M t b$ \\
\hline$M b$ BCG $(0.1 \mathrm{ng} / \mu \mathrm{l})$ & + & - & + & + & + & $M b$ \\
\hline \multicolumn{7}{|l|}{ Recent autopsy cases } \\
\hline Paraffin sample $M b$ & + & - & - & - & + & $M b$ \\
\hline Paraffin sample $M t b$ & - & - & - & - & + & $M t b$ \\
\hline \multicolumn{7}{|l|}{ Historic tissue samples } \\
\hline TT453-9 & + & - & - & - & + & $M t b$ \\
\hline TT453-14 & + & - & - & - & + & $M t b$ \\
\hline TT95-122 & + & - & - & + & + & $M t b$ \\
\hline TT95-40 & - & - & - & + & + & $M t b$ \\
\hline TT95-169 & - & - & - & - & + & $M t b$ \\
\hline DAN93-11 & + & + & - & - & + & $M t b$ \\
\hline DAN95.1-1 & + & - & + & + & + & $M t b$ \\
\hline TT196-M5 & - & - & - & - & + & Mafr \\
\hline
\end{tabular}

$-=$ no result $;+=$ positive result $; \mathrm{Mtb}=$ M. tuberculosis; $\mathrm{Mb}=$ M. bovis; $\mathrm{Mafr}=$ M. africanum 
samples. Initial PCR-based genotyping showed that two samples were classified as PGG2, five samples were classified as PGG3, while five other samples were classified as not PGG1 but either genetic groups 2 or 3 based on the polymorphic regions of the $k a t G$ and gyrA genes. Samples from three individuals in a family group were analysed further using PCR for $m t p-40$, oxyR, plcD, MT18101-plcD, as well as the RD7 deletion, in an attempt to distinguish M. tuberculosis from M. bovis. Molecular fingerprinting of the MTBC DNA was carried out using spoligotyping. The results of the oxyR pseudogene (guanine at position 185), $m t p-40$ (positive), plcD-cutinase (positive) and RD7 (no product obtained) indicated the presence of M. tuberculosis rather than M. bovis DNA. Moreover, spoligotyping patterns obtained from all samples demonstrated the presence of M. tuberculosis DNA: one sample matched $M$. tuberculosis type 53 and two samples matched the profile of $M$. tuberculosis type 50 [65]. One of the individuals in this family group gave excellent results in a recent study based on shotgun sequencing and WGS [34]. A follow-up study based on 26 bodies from the Vác crypt demonstrated that all were of lineage 4, associated with European populations. Eight individuals were examined in depth and five had mixed M. tuberculosis infections with two, or in one case, three strains of different sub-lineages [66].

In 2003, Mays and Taylor described a case of tuberculosis from prehistoric times, which may be the oldest from Britain. They investigated remains excavated at the archeological site in Tarrant Hinton, England dated to 400-230 BC, which belonged to an individual suffering from an infectious disease, most likely tuberculosis. Nested PCR of the multi-copy element IS6110 was performed in an attempt to confirm the presence of MTBC DNA and, hence, the diagnosis of tuberculosis. Four separate DNA extracts were prepared from bone powder sampled from vertebrae and ribs, and three of them were positive. Furthermore, two extracts of DNA from burials without any evidence of infection, which were studied as control samples, yielded negative results. PCR analysis for Brucella DNA was also undertaken using the IS6501 multicopy insertion element. Samples positive for MTBC DNA were further examined for polymorphisms using the oxyR pseudogene and the RD7 deletion, to distinguish M. bovis, M. africanum and M. microti from M. tuberculosis. In an attempt to provide information about the genotypic group, extracts were analysed for polymorphic sites in the katG 463, katG 203 and gyrA loci. Only one marker, IS6110, was efficiently amplified, probably due to the poor degree of DNA preservation [67]. This same case was re-examined in 2005 [39] in order to determine whether the Tarrant Hinton individual had suffered from tuberculosis due to M. tuberculosis or $M$. bovis and to perform further genotypic analysis of the Iron Age strain. To confirm that extracts prepared for this study were also positive for MTBC DNA, nested PCR for IS6110 was carried out. Amplification of the IS1081 sequence yielded positive results. Furthermore, two loci frequently used for differentiation between M. tuberculosis and M. bovis strains ( oxyR and $p n c A)$ were analysed and gave positive results. Sequencing of the obtained PCR products showed guanine at position 285 (oxyR locus) and adenine at position 169 (pncA). Both results confirmed that $M$. tuberculosis DNA rather than $M$. bovis DNA was present in the analysed sample. The M. tuberculosis D1 deletion locus was also examined and identified the strain as a 'modern' TbD1-deleted M. tuberculosis isolate [39].

Ten samples from 18th century burials in Kaiserebersdorf Castle in Austria, now in the collection at the Natural History Museum Department of Anthropology in Vienna, Austria were investigated for the presence of MTBC DNA. Three bone samples from the anatomical 'Weisbach collection' were used as positive controls and two bone samples from a site at Hainburg were used as negative controls. PCR amplifications targeting IS6110, IS1081, oxyR, pncA and TbD1 regions of MTBC DNA, followed by cloning and DNA sequencing were performed. Despite the fact that PCR products of appropriate size were obtained for several bone samples, only PCR targeting the IS6110 region in one sample yielded a product with a sequence identical to the reference IS6110 insertion sequence of M. tuberculosis. Other PCR products were likely the results of non-specific PCR amplification. This failure to obtain a positive diagnosis of $M$. tuberculosis DNA in human remains was probably due to the poor aDNA preservation status of these bones from museum collections [68]. The preservation of the aDNA in a sample is not related to its age but to the local environmental conditions over time. For example, IS6110, together with the repetitive element IS1081, was successfully used in the molecular analysis of Neolithic skeletons (5400-4800 BC) from central Germany [14] and Hungary [6], dating from 4970-4490 BC.

Bouwman et al. used an NGS approach which involved hybridisation capture directed at specific polymorphic fragments of the M. tuberculosis genome, as well as a conventional PCR approach, to genotype a historic strain of M. tuberculosis from an individual dated to the 19th century $\mathrm{AD}$, originating from St. George's Crypt in Leeds, West Yorkshire, England. The SNP data obtained enabled a comparison between this strain and extant isolates of M. tuberculosis. This enabled the assignment of the historic strain into lineage II, SCG $6 \mathrm{~b}$ and SNP type (ST) 14 or 40 . Thirteen loci successfully typed by the conventional PCR approach confirmed the accuracy of the NGS results, demonstrating that NGS is a valuable method that can be used in investigating ancient varieties of $M$. tuberculosis [31].

In 2014, Müller et al. carried out a biomolecular analysis of MTBC DNA isolated from the remains of individuals living between the 1st and 19th centuries AD found at 29 British sites (59 samples) and eight continental European sites (11 samples). Both IS1081 quantitative PCR and IS6110 PCR 
were performed on each sample. Twelve samples definitely contained MTBC DNA (IS6110 PCR was positive in at least two extracts). However, the diagnosis of a further 22 cases was described as probable or possibly containing DNA of the MTBC (IS6110 PCR or IS1081 real-time PCR positive in one of the extracts). Forty-three other samples produced no amplicons from any of the targeted sequences [69]. Thirty-four bone and dental samples from 31 individuals with positive results of IS 6110 and IS 1081 PCRs were characterised further. Conventional PCR of 11 SNPs and two LSPs was performed in an attempt to classify MTBC strains into 1-3 principal genetic groups (PGGs; gyrA 284, $k a t G$ 1388), I-IV lineages and M. bovis (oxyR 37, oxyR 285, rров 2646, гров 3243), 1-7 SCGs (leuB, qcrB, recN, Rv0083, Rv2802c), 'modern' M. tuberculosis (TbD1deleted) and the Euro-American lineage of modern M. tuberculosis (pks15/1-deleted). Data obtained from ten samples allowed categorisation of the MTBC according to their SNP identities, appearance of the TbD1 locus and/or the occurrence of deletion within pks 15/1. PCGs and SCGs were successfully defined in two independent extracts from six samples. The results are summarised in Table 5 [70].

Although recent studies have investigated whether human cases of tuberculosis have been caused by M. bovis, there is only one good example from Iron-Age south Siberia, where semi-nomadic pastoralists overwintered with their animals [71]. This was diagnosed by a genotypic analysis of the aDNA using PCR based on regions of difference (RD) sites. In another and unexpected finding, the use of NGS has revealed that 1000-year-old pre-Columbian Peruvian human skeletons were infected with a member of the MTBC that appears to be $M$. pinnipedii, which is normally associated with sea mammals. This raises many questions but it is suggested that these individuals, who lived by a river that flows to the Pacific Ocean, may have become infected by contact with seals [72].
In summary, it is clear that the detection and characterisation of aDNA from M. tuberculosis, $M$. bovis and the MTBC is well advanced, in line with the strong interest in the modern disease.

Figure 3 shows molecularly investigated ancient MTBC cases presented in this review.

\section{Molecular investigations of ancient leprosy}

The first case of ancient leprosy to be subjected to molecular examination, dating from the first millennium, was obtained from a leprosarium, now in modern Israel [23, 24]. the results were initially queried, as the PCR target region was for a 530bp target in the $36 \mathrm{kDa}$ antigen locus. It was thought to be too large, but recent studies illustrate the remarkable preservation of M. leprae aDNA in some samples [33]. Another individual case of leprosy investigated by this group used PCR as paleopathologists could not agree on the cause of the visible bony lesions [73]. Meanwhile, Haas et al. from Münich undertook a molecular study of leprosy from a 10th century cemetery in Hungary and a South German ossuary of a later date [74], basing their samples on bone paleopathology. M. leprae DNA was amplified and sequenced. In addition, evidence was obtained of M. tuberculosis in another specimen.

The first recognised case of leprosy in Mediaeval Poland, from Suraż, dated to the 12th-14th centuries AD [4]. This case was included in a molecular study alongside archaeological samples with lesions from Hungary (one sample dated to 14th-15th century AD and two samples dated to 10th-11th century $\mathrm{AD})$. M. leprae nested PCR for the specific repetitive element RLEP (36 copies per cell) and the $18 \mathrm{kDa}$ antigen gene (single copy per cell), followed by DNA sequencing, were used to detect the target aDNA. This was successfully achieved using extracts from cavum nasale samples [75].

The first British case of leprosy to be subjected to molecular analysis, for the RLEP region, was from a mid-10th
Table 5 Results of ancient M. tuberculosis genotyping obtained in Manchester and Madrid from two independent extracts [70]

\begin{tabular}{|c|c|c|c|c|c|}
\hline & $\mathrm{TbD} 1$ & $p k s 15 / 1$ & PGG & Lineage & SGG \\
\hline \multicolumn{6}{|l|}{ Sample } \\
\hline Ashburch 705 & $-1-$ & $+/+$ & 2 or $3 / 2$ & I or II/nd & $3 / 3$ or 4 \\
\hline Auldhame 43 & $-1 \times$ & $+/+$ & $2 / 2$ & II/nd & $5 / 5$ \\
\hline Saint Amé 20 & $\mathrm{nd} / \times$ & $\mathrm{nd} /+$ & $3 / 3$ & Not IV/not III & $6 / 6$ \\
\hline St. George's Crypt 4006 & $-1-$ & $+/+$ & $3 / 3$ & $\mathrm{II} / \mathrm{II}$ & $6 / 6$ \\
\hline St. George's Crypt 5003 & $\mathrm{nd} /-$ & $+/$ nd & $\mathrm{nd} / \mathrm{nd}$ & Not IV/nd & $6 / \mathrm{nd}$ \\
\hline St. Peter's Church 1390 & $-/ x$ & $+/+$ & $2 / 2$ & I or II/nd & $3 / 3$ \\
\hline St. Peter's Collegiate Church 28 & $-1 \times$ & $+/$ nd & $3 / \mathrm{nd}$ & I or II/nd & $6 / \mathrm{nd}$ \\
\hline St. Peter's Collegiate Church 62 & $-1-$ & $+/+$ & $2 / 2$ & I or II/II & $4 / 4$ \\
\hline Whitefriars 657 & $n d / \times$ & $+/$ nd & $2 / 3$ & I or II/nd & $6 / 6$ \\
\hline Whitefriars 10466 & $-/ x$ & $\mathrm{nd} /+$ & $2 / 2$ & I or II/nd & $4 / 4$ \\
\hline
\end{tabular}


Fig. 3 Examples of analytical methods used to identify MTBC aDNA in selected European sites

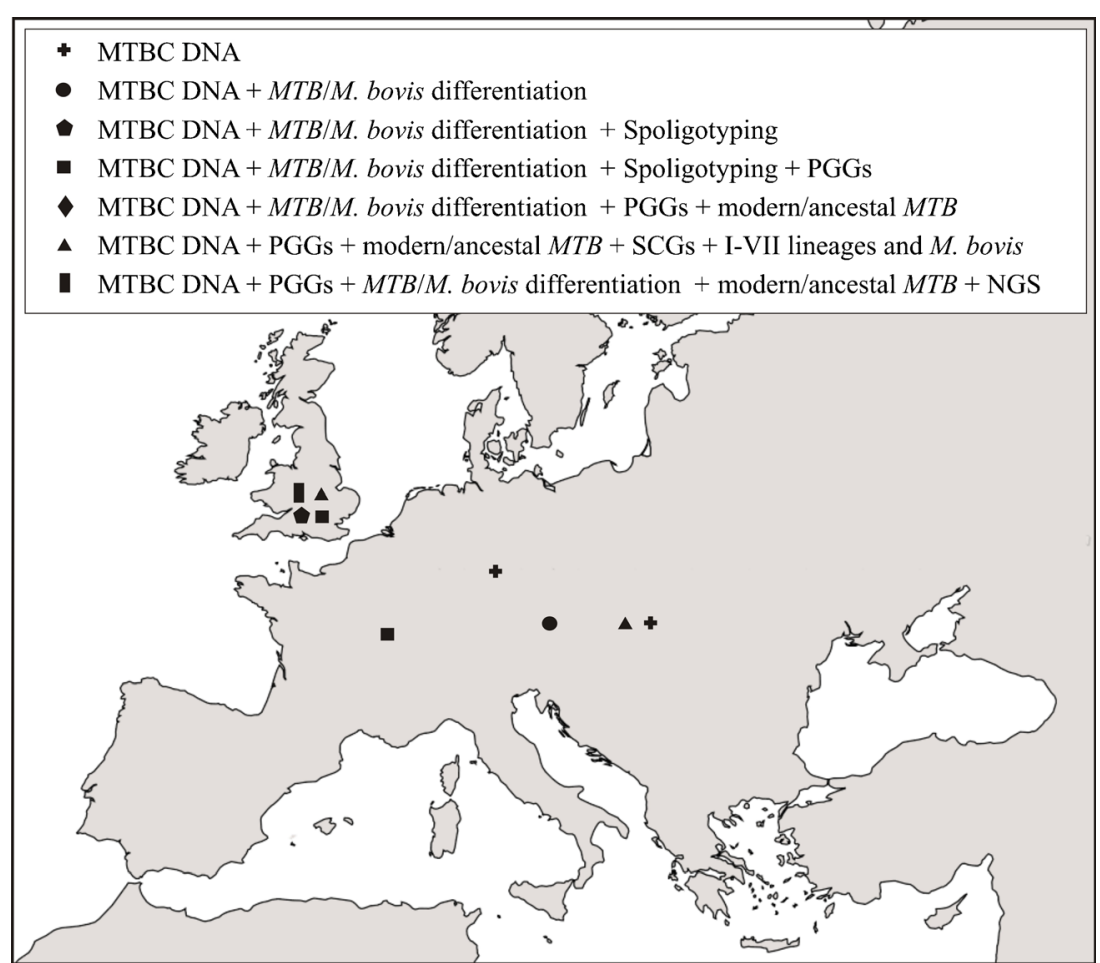

century burial in a Norse Christian cemetery in Orkney, Scotland [76]. In 2006, Taylor et al. examined two individuals, with demonstrable osteological evidence of lepromatous leprosy, from two English Mediaeval sites: Wharram Percy, Yorkshire (burial G708 radiocarbon dated to 960-1100 AD) and Blackfriars Friary, at Ipswich, Suffolk (burial 1914 radiocarbon dated to 1263-1538 AD). Again, the sensitive multicopy RLEP PCR was used to confirm the presence of M. leprae DNA and both burials were found to be positive. VNTR typing was used to assess genetic variability between strains in these cases and also a modern reference strain of M. leprae. The microsatellite regions, AGT and TTC, and one minisatellite region containing exact copies of a 21-bp repeat, were genotyped. The VNTR analysis (Table 6) and genotyping demonstrates differences between modern and historical M. leprae and between the two strains from investigated burials [77].

Watson et al. sought evidence of $M$. leprae DNA in ancient European remains from Croatia, Denmark and the UK. They were dated to 476-1350 AD and examined by RLEP PCR and
SNP typing. RLEP PCR was positive in three samples from the UK, one sample from Denmark and two samples from Croatia. DNA extracts that were positive for the RLEP sequence were further typed. All examined samples were of SNP type 3 [78] (corrected 2010 [79]). The genotyping study of both modern and ancient strains of $M$. leprae [55] identified the Hungarian strains as genotype $3 \mathrm{~K}$ or 3M. In 2011, Taylor and Donoghue used three variable VNTR loci, AGT, TTC and 21-3, to characterise $M$. leprae from five archeological sites with a confirmed presence of $M$. leprae DNA and known SNP types and subtypes: Hungary, cases 503 and 222 (10th century), KD271 (7th century); the Czech Republic, burial 188 (9th-10th century) and northern Byzantine Turkey, KK '02 20/1 (8th-9th century). All the examined samples were found to have distinct MLVA profiles. Furthermore, an individual (burial 1914, 13th-16th century) from Ipswich, Suffolk [77] was genotyped as SNP subtype 3I [80]. The 2006 study [77] also confirmed that a leprosy case from Uzbekistan, dated to the $1 \mathrm{st}-4$ th centuries AD, was of genotype $3 \mathrm{~L}$, the only known example from aDNA analysis.
Table 6 VNTR typing of two medieval leprosy cases from Wharram Percy and Blackfriars Friary compared to modern leprosy DNA [77]

\begin{tabular}{cccc}
\hline & $\begin{array}{l}\text { Individual from Wharram Percy } \\
\text { Number of repeats }\end{array}$ & Individual from Blackfriars Friary & Modern DNA \\
\hline AGT & 8 & 9 & 10 \\
TTC & 10 & 12 & 13 \\
21-bp repeat & 3 & 2 & 2 \\
\hline
\end{tabular}


Rubini et al. examined two cases of childhood leprosy from the ancient Roman and Byzantine Empire. The first case was a skeleton of a 4-5-year-old child from a Roman cemetery at Martellona dated to the 2 nd-3rd centuries AD. The second case, a 4-5-month-old infant was from a burial at Kovuklukaya in northern Byzantine Turkey, as mentioned above. Both skeletons exhibited bony changes indicative of leprosy. RLEP PCR was positive only for the second case and, at present, it is the youngest individual in the world proved to have suffered from leprosy in the past [81].

An early molecular study of leprosy in Sweden [82] demonstrated $M$. leprae aDNA from the Viking era. Subsequently, Economou et al. examined ten skeletons, from two cemeteries in Sigtuna, Sweden dated to the 9th-13th century AD, for $M$. leprae genomic sequences. Eight of those individuals had formerly been described as exhibiting bone changes characteristic for leprosy. RLEP PCR analysis was performed and nine specimens were positive for the repetitive RLEP element. SNP typing was possible in three samples: one was characterised as SNP type 3I and two as SNP type 2F. The remaining specimens either yielded no amplicons or results for one or two loci only. SNP type 3I has been described in a number of cases from ancient Europe. SNP type $2 \mathrm{~F}$ had never been reported in Europe before and was previously considered as Asian [83]. Taylor et al. sampled nine skeletons showing good osteological signs of leprosy and bone preservation, originating from the St. Mary Magdalene leprosy hospital site in Winchester, UK. Two skeletons with no signs of leprosy were also sampled as negative controls. The presence of $M$. leprae DNA was investigated using the multicopy element RLEP, as well as the single copy $18 \mathrm{kDa}$ antigen gene. Samples were subsequently characterised by SNP and MLVA typing. The results of $M$. leprae fingerprinting are shown in Table 7. Two SNP types were obtained during studies: 3I-1 and 2F. SNP type 3I-1 has been observed previously in the UK and confirms the association of SNP type 3 strains with Europe. However, SNP type $2 \mathrm{~F}$ has never been described in the UK before and has formerly been reported in Asia and lately in Scandinavia [84]. Other cases from England and Scandinavia also appear to be predominantly of genotypes $2 \mathrm{~F}$ or 3I [33, 85], suggesting that SNP types 2 and 3 co-existed in Mediaeval Europe.

DNA bead capture and high-throughput sequencing (NGS) were used by Schuenemann et al. to obtain complete genome sequences of $M$. leprae from skeletons from five Mediaeval archeological sites in the UK, Sweden and Denmark. These were compared with 11 modern strains. Bayesian phylogeny inference, maximum likelihood, neighbour joining and maximum parsimony were used to calculate the phylogenetic trees of all genomes. The majority of the examined strains clustered into four major branches supported by bootstrap values of $>90 \%$ for all major nodes. This is consistent with the SNP typing scheme. Two modern strains had the deepest lineage and formed a new branch 0 . One modern strain displayed deep divergence and did not fit definitely into one branch. These three different strains were found to be those closest to the suggested common ancestor of $M$. tuberculosis, M. leprae, M. avium and M. ulcerans. The nucleotide distance of 16 sequences to the reconstructed most recent common ancestor (MRCA) of all M. leprae strains was calculated in an attempt to verify if the ancient $M$. leprae strains have shorter branches in a phylogenetic tree compared to the modern branches. The average distance to the MRCA for the ancient strains was 19.8 nucleotides and for the modern strains it was 27.5 nucleotides.
Table 7 Genotyping of nine individuals from the St. Mary Magdalene leprosy hospital site in Winchester, UK [84]

\begin{tabular}{|c|c|c|c|c|c|c|c|}
\hline & \multirow[t]{2}{*}{ RLEP } & \multirow[t]{2}{*}{$18 \mathrm{kDa}$ antigen } & \multirow[t]{2}{*}{ SNP typing } & \multicolumn{3}{|c|}{ MLVA typing } & \multirow[b]{2}{*}{ IS1081* } \\
\hline & & & & $\operatorname{AGA}(20)$ & $(\mathrm{GTA}) 9$ & 21-3 loci & \\
\hline \multicolumn{8}{|c|}{ Negative control } \\
\hline Sk1 & - & - & $\times$ & $x$ & $\times$ & $x$ & - \\
\hline Sk12 & - & - & $x$ & $x$ & $\times$ & $x$ & - \\
\hline \multicolumn{8}{|l|}{ Samples } \\
\hline Sk2 & + & + & $3 \mathrm{I}-1$ & 11 & 8 & 2 & - \\
\hline $\mathrm{Sk} 7$ & + & $+*$ & $3 \mathrm{I}-1$ & 13 & 8 & 2 & - \\
\hline Sk8 & + & + & $2 \mathrm{~F}$ & 14 & 8 & 2 & - \\
\hline Sk9 & $+^{*}$ & - & $\times$ & $x$ & $\times$ & $\times$ & - \\
\hline Sk14 & + & + & $2 \mathrm{~F}$ & 14 & 8 & 2 & - \\
\hline Sk15 & $+*$ & - & $\times$ & $\times$ & $x$ & $x$ & - \\
\hline Sk18 & $+^{*}$ & - & $\times$ & $\times$ & $\times$ & $\times$ & - \\
\hline Sk19 & + & $+*$ & $3 \mathrm{I}-1$ & 14 & 7 & Fail & - \\
\hline Sk23 & $+*$ & $+*$ & $\times$ & $\times$ & $x$ & $x$ & - \\
\hline
\end{tabular}

$-=$ no result $;+=$ positive result $;+*$ weakly positive result; $\times=$ no analysis was done 
The ancient strains displayed significantly shorter branches in the tree. Strains assigned to branch 2 formed a tight cluster with very short branch lengths. Branch 3 strains are found in European ancient samples and in modern samples from America, indicating the European origin of leprosy in the Americas. SNP subtyping was performed also for individuals from 11th14th century AD, Denmark and assigned to $3 \mathrm{I}$ and $2 \mathrm{~F}$ groups, the same as that reported by others [33, 83, 84]. Variations in the $M$. leprae subtype 3I have been found [84] and, in a recent study of a 5th-6th century male from Essex, East England [86], the authors suggest that this $M$. leprae strain was ancestral to the Mediaeval strains and may have originated in Scandinavia. Using collated evidence of the distribution of M. leprae in ancient and historical Europe, based on genotyping where possible, Donoghue et al. have suggested that the differences between subtypes in central and east Europe, compared with northwest Europe, may be linked to human migration [5].

All molecularly investigated cases of ancient leprosy described in the review are presented in Fig. 4.

\section{Significance of the host genome in mycobacterial diseases}

Investigation of the aDNA from human pathogens enables the assessment of disease epidemiology in past millennia. Development of mycobacterial diseases, as for many other infectious conditions, depends on both environmental and genetic factors, i.e. host and pathogen genomes. Only about $10 \%$ of carriers of M. tuberculosis develop the disease, thereby indicating the importance of alleles coding for resistance in the formation of a pathogen-resistant phenotype [87]. However, it should also be remembered that other non-genetic factors influence human susceptibility to infection, such as co-morbidity, co-infections, dietary deficiencies, stress and trauma [88]. The significance of the host genome in the development of mycobacterial diseases has been confirmed by studies on mono- and di-zygotic twins and by documented differences in disease incidence around the world, correlated with the history of the disease in different regions [89]. The immunological resistance to leprosy and tuberculosis has developed under strong selective pressures, such as epidemics, which have promoted the survival of the best-adapted individuals and changed the composition of the gene pool, i.e. increased the frequency of resistance-related alleles. Therefore, the presence of pathogens in human populations has left a strong mark and the differences between ancient and present gene pools can elucidate the course of major epidemics and help resolve any doubts about the time of disease origin. Moreover, studies based on changes in the frequency of resistance-related alleles provide information about whole populations rather than individuals, where data are gained by the examination of pathological bone lesions. A broader paleopathological approach that combines population genetics with the molecular analysis of pathogens responsible for infectious disease constitutes a promising tool of much greater power in reconstructing human history rather than using a single-approach analysis.
Fig. 4 Examples of analytical methods used to identify M. leprae aDNA in selected European sites

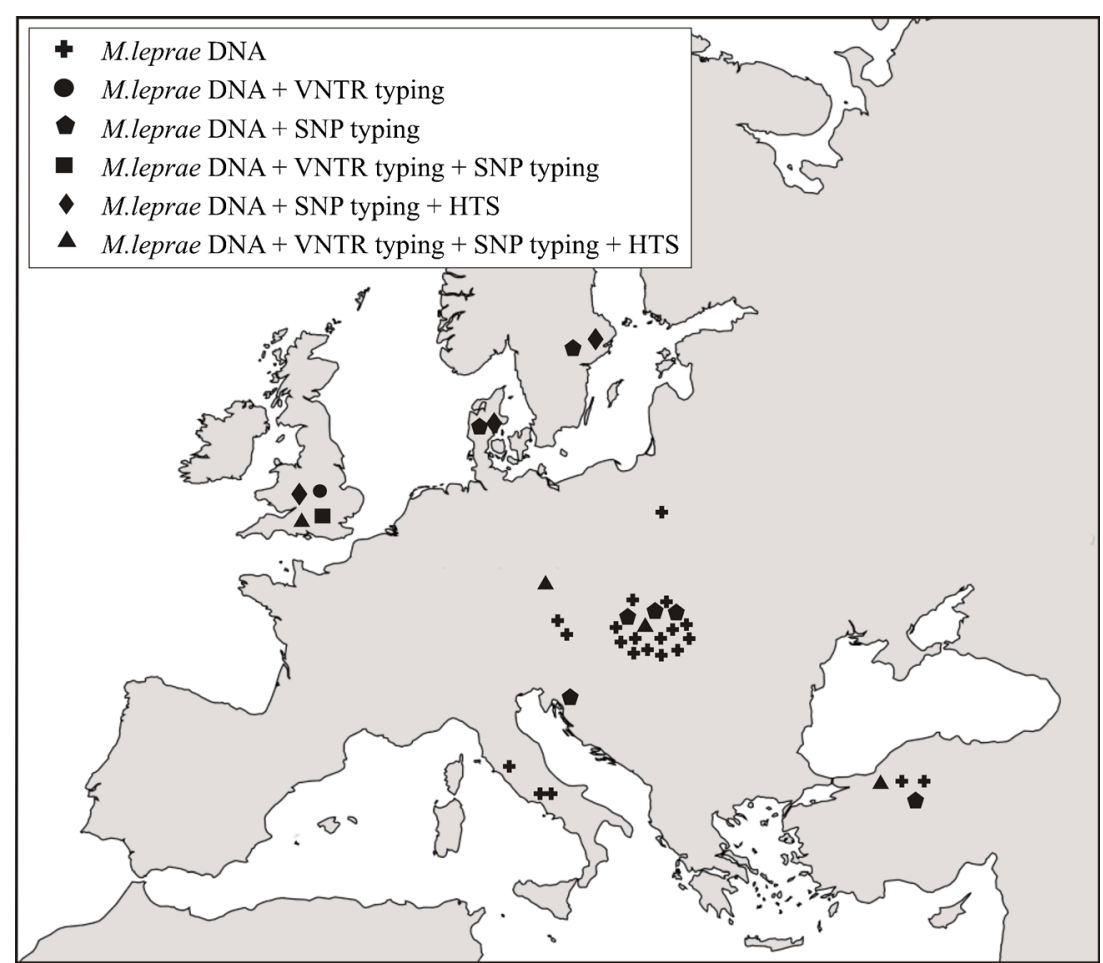




\section{Genes involved in genetic predisposition to leprosy and tuberculosis}

Genetic predisposition to tuberculosis and leprosy is still a subject of extensive investigation due to the complexity of reactions induced by mycobacteria. Owing to intensive research including family-based and case-control studies, several polymorphisms can be linked to mycobacterial diseases. Candidate genes linked to a tuberculosis-susceptible genotype involve a great number of immunological response components, such as cytokines, chemokines and receptors. However, some genes with influence on tuberculosis development are well investigated and confirmed. Examples are genetic alleles of mannose-binding lectin (MBL2), interleukins (IL1, IL6, IL8, IL10), interferon (IFNG), receptors (PR2X7, TLR1, $T L R 2)$ and human leukocyte antigens [87, 90, 91]. Nevertheless, the strongest evidence for genetic susceptibility to both tuberculosis and leprosy is based on the solute carrier family 11 SLC11A1, formerly known as natural resistance-associated macrophage protein 1 (NRMAP1) [92]. It encodes a divalent cation transporter build of 550 amino acids which is recruited to the phagolysosomal membrane during phagocytosis in macrophages and neutrophils [93].

Killer cell immunoglobulin-like receptors (KIRs) are members of a group of regulatory molecules found on subsets of lymphoid cells, first identified by their ability to impart some specificity on natural killer (NK) cytolysis. The KIR locus, which maps to chromosome $19 \mathrm{q}(13.4)$ within the $1 \mathrm{Mb}$ leukocyte receptor complex (LRC), contains a family of polymorphic and highly homologous genes. The KIR molecules recognise the human leukocyte antigen (HLA) class I molecules, which are encoded by genes within the major histocompatibility complex (MHC) chromosome 6 [94]. Interactions occur between KIR isotypes that inhibit NK cell activity. Recent studies report a greater repertoire of inhibitory KIR genes among tuberculosis patients than controls [95] and a direct association of certain KIR and HLA-C genes [96] with resistance to pulmonary tuberculosis.

Several SLC11A1 polymorphisms (e.g. 3'UTR, D543N, 5' (GT)n, INT4) have been linked to host genetic predisposition to both leprosy and tuberculosis in various populations, making it a common rather than a local susceptibility-related gene. To estimate the role of this ion transporter in forming resistant genotypes, Barnes et al. [97] determined the frequency of one allele (SLC11A1 1729+55de14) in various populations from global cities with a different length of time since urbanisation. Interestingly, in longer-term urbanised populations, the incidence of the protective allele was significantly higher as a result of natural selection. Their studies support the thesis that urbanisation and population density determine the general health status of the population and influence its genetic structure. Moreover, an initial study on the comparison of allele frequencies (SLC11A1, MBL2) that formed part of a Ph.D. dissertation revealed interesting discrepancies between medieval and contemporary Polish populations [98]. Samples from various 11 th -14 th century archaeological sites displayed a consistent pattern of a significantly higher frequency of alleles predisposing to infectious diseases compared with the contemporary Polish population. The results point to a positive selection of protective variants over time, most probably due to past epidemics.

Susceptibility to leprosy depends on various mutations within several genes, for example, the major histocompatibility complex (HLA-DR, HLA-DQ), tumour necrosis factor $\alpha$ (TNFA), Toll-like receptors (TLR1, TLR2, TLR4, TLR9), vitamin D receptor (VDR) or cytotoxic T cell antigen 4 (CTLA4), among others $[89,99,100]$. However, the predisposition to mycobacterial diseases depends upon the ethnic group, which makes it difficult to determine one genotype responsible for susceptibility to leprosy. The best-described leprosy-related genetic markers are regulatory polymorphisms within PARK2/ $P A C R G$ genes. Even though the function of the Parkin gene is still unknown, it has been proved that two polymorphisms within the 6q25 locus are involved in susceptibility to paucibacillary and multibacillary leprosy [101, 102]. BakijaKonsuo et al. measured the frequency of selected changes in the isolated population of Mljet island in Croatia, used in the past to quarantine for leprosy patients, and compared it with the reference populations with no history of leprosy [103]. They found a significant increase in the frequency of both protective alleles, indicating their positive selection in the course of high disease prevalence and demonstrating the importance of host genotype and changes in population gene pools under high selective pressure.

According to John Haldane, 1949, cited by Bellamy in 2005 [90], pathogens have been the major agents for natural selection over the last 5000 years. He suggested that natural selection was driven mainly by the necessity to resist pathogens, as they were the main cause of premature deaths in the past [90]. Between the 18th and 19th centuries, during the Industrial Revolution in Europe, fast development and the human population explosion, as well as the probable increase of pathogen virulence, initiated a huge increase in tuberculosis, which caused one-fifth of all deaths. The low incidence of tuberculosis in Europe in the recent past indicates that the development of tuberculosis depends predominantly on the host genome rather than the pathogen. Therefore, the frequencies of selected alleles that predispose to tuberculosis and leprosy among past populations of different ages could elucidate the susceptibility/resistance status of selected populations and, thus, the presence of pathogenic mycobacteria in that period. Even though the history of both tuberculosis and leprosy is moderately understood, there are still many aspects that require resolution, including the time of the emergence of these mycobacterial diseases in Europe. The comparison of various populations can provide data about the dynamics of change 
and distinguish the role of each allele in the process of resistant phenotype formation. Thus, further research on host genes related to susceptibility/resistance to mycobacterial diseases is crucial in order to identify the mycobacterial resistant genotype in different populations and enabling the recognition of changes in allele frequencies. Extending this to aDNA studies, limited data are now available for amplified aDNA from 18 individuals from the 18th century Vác, Hungary and early Christian Nubia [88].

\section{Other applications of susceptibility studies}

Research on genetic susceptibility among ancient populations complements work on paleoepidemiology. These have mainly focused on the pathogen, and have already been successfully employed in several studies. In 2006, Witas et al. assessed the frequency of the $\triangle 32-C C R 5$ mutation in a medieval Polish population and compared it with the contemporary gene pool $[104,105]$. The deletion of a 32-bp sequence in the coding region of this chemokine receptor leads to the perturbation of its fusion to the cell membrane [106]. The lack of two functional copies of the CCR 5 gene results in the absence of the leucocyte surface receptor and results in a strong but incomplete resistance to HIV-1 infection. The area of mutation occurrence is restricted mainly to Europe and parts of Asia. Its frequency in Europe varies according to the region, from $4 \%$ in Sardinia to $15 \%$ in Finland [107]. In present-day Poland, the incidence is similar to the European average of $10.9 \%$ [108]. However, the frequency of this protective allele in the medieval Polish population (11th-14th century) was half as great (5.06\%), which may signal the positive selection due to the protecting allele during this time period $[104,105]$. These results conflict with the alternative suggestion that Yersinia pestis was a selective factor for $\triangle 32-C C R 5$, as the timing of plague epidemics does not match the likely emergence of the deletion and the origin of this mutation remains unsolved. Meanwhile, Fontecchio et al. have attempted to answer the question about the susceptibility to rheumatoid arthritis (RA) in the decay of the Middle Ages. It is commonly believed that the disease was brought to Europe from America at the end of the 15th century. The genetic predisposition to RA, based on the polymorphic HLA-DRB1 locus, which was carried by an early case known as the 'Braids Lady' from Arezzo (Italy), combined with pathomorphological lesions characteristic for this condition. This confirms the presence of RA in the Old World in the mid-16th century and brings us closer to answering the question about the worldwide diffusion of rheumatoid arthritis [109].

\section{Summary}

Emerging molecular approaches employed in the investigation of M. tuberculosis and M. leprae in ancient human remains began a new era of paleopathological analysis. The techniques described have been applied successfully in several European studies, revolutionised the classical approach to ancient disease studies and accelerated the development of paleomicrobiology. As the molecular analysis of bacteria from ancient material has become widespread, it is possible to determine their phylogenetic affiliation. Therefore, studies of bacteria from different times and locations will undoubtedly enable a better understanding of the origin of infectious diseases. The novel techniques of aDNA sequencing have enabled the identification of genes related to susceptibility and resistance phenotypes within ancient populations, which may be an important factor in the determination of past bacterial prevalence. Methods have been reviewed and changes in population immunological profiles over time are assessed. The overall aim is to reach a better understanding of the history of tuberculosis and leprosy and to determine the timescale of major outbreaks. However, the complexity of the immune response induced by mycobacterial infections, such as the great number of gene polymorphisms involved in host susceptibility, constitutes a major problem in employing such methods in paleoepidemiology. Nevertheless, the progress in elucidating host genetic profiles, linked to the predisposition of susceptibility or resistance to infection, is enabling a better understanding of the course of two major historical diseases in the human population.

Conflict of interest The authors declare that they have no conflict of interest.

Open Access This article is distributed under the terms of the Creative Commons Attribution 4.0 International License (http:// creativecommons.org/licenses/by/4.0/), which permits unrestricted use, distribution, and reproduction in any medium, provided you give appropriate credit to the original author(s) and the source, provide a link to the Creative Commons license, and indicate if changes were made.

\section{References}

1. Roberts CA, Buikstra JE (2003) The bioarchaeology of tuberculosis: a global view on a reemerging disease. University Press of Florida, Gainsville

2. Ortner DJ (2003) Identification of pathological conditions in human skeletal remains. Academic Press, Amsterdam

3. Robbins G, Tripathy VM, Misra VN, Mohanty RK, Shinde VS, Gray KM, Schug MD (2009) Ancient skeletal evidence for leprosy in India (2000 B.C.). PLoS One 4(5):e5669

4. Gładykowska-Rzeczycka J (2009) Sources, methods and documentation in paleopathology and archeopathology. In: Dzieduszycki W, Wrzesiński J (eds) Methods, sources, documentation. Funeralia at Lednica. Scientific Association of Polish Archaeologists, Poznań Branch, Poznań, pp 83-92

5. Donoghue HD, Michael Taylor G, Marcsik A, Molnár E, Pálfi G, Pap I, Teschler-Nicola M, Pinhasi R, Erdal YS, Velemínsky P, Likovsky J, Belcastro MG, Mariotti V, Riga A, Rubini M, Zaio P, Besra GS, Lee OY, Wu HH, Minnikin DE, Bull ID, O’Grady J, 
Spigelman M (2015) A migration-driven model for the historical spread of leprosy in medieval Eastern and Central Europe. Infect Genet Evol 31:250-256

6. Masson M, Molnár E, Donoghue HD, Besra GS, Minnikin DE, Wu HH, Lee OY, Bull ID, Pálfi G (2013) Osteological and biomolecular evidence of a 7000-year-old case of hypertrophic pulmonary osteopathy secondary to tuberculosis from neolithic Hungary. PLoS One 8(10):e78252

7. Lee OY, Wu HH, Besra GS, Rothschild BM, Spigelman M, Hershkovitz I, Bar-Gal GK, Donoghue HD, Minnikin DE (2015) Lipid biomarkers provide evolutionary signposts for the oldest known cases of tuberculosis. Tuberculosis (Edinb). doi: 10.1016/j.tube.2015.02.013

8. Zink AR, Grabner W, Nerlich AG (2005) Molecular identification of human tuberculosis in recent and historic bone tissue samples: the role of molecular techniques for the study of historic tuberculosis. Am J Phys Anthropol 126(1):32-47

9. Donoghue HD, Spigelman M, Greenblatt CL, Lev-Maor G, BarGal GK, Matheson C, Vernon K, Nerlich AG, Zink AR (2004) Tuberculosis: from prehistory to Robert Koch, as revealed by ancient DNA. Lancet Infect Dis 4(9):584-592

10. World Health Organization (WHO) (2014) Global tuberculosis report 2013. WHO

11. World Health Organization (WHO) (2014) The weekly epidemiological record (WER). WHO, pp 389-400

12. Baker O, Lee OY, Wu HH, Besra GS, Minnikin DE, Llewellyn G, Williams CM, Maixner F, O'Sullivan N, Zink A, Chamel B, Khawam R, Coqueugniot E, Helmer D, Le Mort F, Perrin P, Gourichon L, Dutailly B, Pálfi G, Coqueugniot H, Dutour O (2015) Human tuberculosis predates domestication in ancient Syria. Tuberculosis (Edinb). doi:10.1016/j.tube.2015.02.001

13. Hershkovitz I, Donoghue HD, Minnikin DE, Besra GS, Lee OY, Gernaey AM, Galili E, Eshed V, Greenblatt CL, Lemma E, BarGal GK, Spigelman M (2008) Detection and molecular characterization of 9,000-year-old Mycobacterium tuberculosis from a Neolithic settlement in the Eastern Mediterranean. PLoS One 3(10): 3426

14. Nicklisch N, Maixner F, Ganslmeier R, Friederich S, Dresely V, Meller H, Zink A, Alt KW (2012) Rib lesions in skeletons from early neolithic sites in Central Germany: on the trail of tuberculosis at the onset of agriculture. Am J Phys Anthropol 149(3):391-404

15. Formicola V, Milanesi Q, Scarsini C (1987) Evidence of spinal tuberculosis at the beginning of the fourth millennium $\mathrm{BC}$ from Arene Candide cave (Liguria, Italy). Am J Phys Anthropol 72(1): $1-6$

16. Canci A, Minozzi S, Tarli SMB (1996) New evidence of tuberculous spondylitis from Neolithic Liguria (Italy). Int J Osteoarchaeol 6(5):497-501

17. Spigelman M, Lemma E (1993) The use of the polymerase chain reaction (PCR) to detect Mycobacterium tuberculosis in ancient skeletons. Int J Osteoarchaeol 3(2):137-143

18. Salo WL, Aufderheide AC, Buikstra J, Holcomb TA (1994) Identification of Mycobacterium tuberculosis DNA in a preColumbian Peruvian mummy. Proc Natl Acad Sci U S A 91(6): 2091-2094

19. Robbins Schug G, Blevins KE, Cox B, Gray K, Mushrif-Tripathy $\mathrm{V}$ (2013) Infection, disease, and biosocial processes at the end of the Indus Civilization. PLoS One 8(12):e84814

20. Mariotti V, Dutour O, Belcastro MG, Facchini F, Brasili P (2005) Probable early presence of leprosy in Europe in a Celtic skeleton of the 4th-3rd century BC (Casalecchio di Reno, Bologna, Italy). Int J Osteoarchaeol 15(5):311-325

21. Tayles N, Buckley HR (2004) Leprosy and tuberculosis in Iron Age Southeast Asia? Am J Phys Anthropol 125(3):239-256

22. Roberts CA (2002) The antiquity of leprosy in Britain: the skeletal evidence. In: Roberts CA, Lewis ME, Manchester K (eds) The past and present of leprosy. Archaeological, historical, palaeopathological and clinical approaches. Archaeopress, Oxford, pp 213-222

23. Rafi A, Spigelman M, Stanford J, Lemma E, Donoghue H, Zias J (1994) Mycobacterium leprae DNA from ancient bone detected by PCR. Lancet 343(8909):1360-1361

24. Rafi A, Spigelman M, Stanford J, Lemma E, Donoghue H, Zias J (1994) DNA of Mycobacterium leprae detected by PCR in ancient bone. Int J Osteoarchaeol 4(4):287-290

25. Matheson CD, Vernon KK, Lahti A, Fratpietro R, Spigelman M, Gibson S, Greenblatt CL, Donoghue HD, Zissu B (2009) Molecular exploration of the first-century Tomb of the Shroud in Akeldama, Jerusalem. PLoS One 4(12):e8319

26. Höss M, Jaruga P, Zastawny TH, Dizdaroglu M, Pääbo S (1996) DNA damage and DNA sequence retrieval from ancient tissues. Nucleic Acids Res 24(7):1304-1307

27. Lindahl $T$ (1993) Instability and decay of the primary structure of DNA. Nature 362(6422):709-715

28. Pääbo S, Poinar H, Serre D, Jaenicke-Despres V, Hebler J, Rohland N, Kuch M, Krause J, Vigilant L, Hofreiter M (2004) Genetic analyses from ancient DNA. Annu Rev Genet 38:645679

29. Rizzi E, Lari M, Gigli E, De Bellis G, Caramelli D (2012) Ancient DNA studies: new perspectives on old samples. Genet Sel Evol 44:21

30. Gilbert MTP, Hansen AJ, Willerslev E, Rudbeck L, Barnes I, Lynnerup N, Cooper A (2003) Characterization of genetic miscoding lesions caused by postmortem damage. Am J Hum Genet 72(1):48-61

31. Bouwman AS, Kennedy SL, Müller R, Stephens RH, Holst M, Caffell AC, Roberts CA, Brown TA (2012) Genotype of a historic strain of Mycobacterium tuberculosis. Proc Natl Acad Sci U S A 109(45):18511-18516

32. Templeton JE, Brotherton PM, Llamas B, Soubrier J, Haak W, Cooper A, Austin JJ (2013) DNA capture and next-generation sequencing can recover whole mitochondrial genomes from highly degraded samples for human identification. Investig Genet 4(1): 26

33. Schuenemann VJ, Singh P, Mendum TA, Krause-Kyora B, Jäger G, Bos KI, Herbig A, Economou C, Benjak A, Busso P, Nebel A, Boldsen JL, Kjellström A, Wu H, Stewart GR, Taylor GM, Bauer P, Lee OY, Wu HH, Minnikin DE, Besra GS, Tucker K, Roffey S, Sow SO, Cole ST, Nieselt K, Krause J (2013) Genome-wide comparison of medieval and modern Mycobacterium leprae. Science 341(6142):179-183

34. Chan JZ, Sergeant MJ, Lee OY, Minnikin DE, Besra GS, Pap I, Spigelman M, Donoghue HD, Pallen MJ (2013) Metagenomic analysis of tuberculosis in a mummy. N Engl J Med 369(3):289 290

35. Thierry D, Brisson-Noël A, Vincent-Lévy-Frébault V, Nguyen S, Guesdon JL, Gicquel B (1990) Characterization of a Mycobacterium tuberculosis insertion sequence, IS6110, and its application in diagnosis. J Clin Microbiol 28(12):2668-2673

36. Eisenach KD, Cave MD, Bates JH, Crawford JT (1990) Polymerase chain reaction amplification of a repetitive DNA sequence specific for Mycobacterium tuberculosis. J Infect Dis 161(5):977-981

37. Tanaka MM, Small PM, Salamon H, Feldman MW (2000) The dynamics of repeated elements: Applications to the epidemiology of tuberculosis. Proc Natl Acad Sci U S A 97(7):3532-3537

38. McHugh TD, Newport LE, Gillespie SH (1997) IS6110 homologs are present in multiple copies in mycobacteria other than tuberculosis-causing mycobacteria. J Clin Microbiol 35(7):17691771 
39. Taylor GM, Young DB, Mays SA (2005) Genotypic analysis of the earliest known prehistoric case of tuberculosis in Britain. J Clin Microbiol 43(5):2236-2240

40. Mustafa AS, Ahmed A, Abal AT, Chugh TD (1995) Establishment and evaluation of a multiplex polymerase chain reaction for detection of mycobacteria and specific identification of Mycobacterium tuberculosis complex. Tuber Lung Dis 76(4):336-343

41. Taylor GM, Goyal M, Legge AJ, Shaw RJ, Young D (1999) Genotypic analysis of Mycobacterium tuberculosis from medieval human remains. Microbiology 145(Pt 4):899-904

42. van Soolingen D, Hermans PW, de Haas PE, van Embden JD (1992) Insertion element IS1081-associated restriction fragment length polymorphisms in Mycobacterium tuberculosis complex species: a reliable tool for recognizing Mycobacterium bovis BCG. J Clin Microbiol 30(7):1772-1777

43. Sreevatsan S, Pan X, Stockbauer KE, Connell ND, Kreiswirth BN, Whittam TS, Musser JM (1997) Restricted structural gene polymorphism in the Mycobacterium tuberculosis complex indicates evolutionarily recent global dissemination. Proc Natl Acad Sci U S A 94(18):9869-9874

44. Brosch R, Gordon SV, Marmiesse M, Brodin P, Buchrieser C, Eiglmeier K, Garnier T, Gutierrez C, Hewinson G, Kremer K, Parsons LM, Pym AS, Samper S, van Soolingen D, Cole ST (2002) A new evolutionary scenario for the Mycobacterium tuberculosis complex. Proc Natl Acad Sci U S A 99(6):3684-3689

45. Gordon SV, Brosch R, Billault A, Garnier T, Eiglmeier K, Cole ST (1999) Identification of variable regions in the genomes of tubercle bacilli using bacterial artificial chromosome arrays. Mol Microbiol 32(3):643-655

46. Zumárraga MJ, Bernardelli A, Bastida R, Quse V, Loureiro J, Cataldi A, Bigi F, Alito A, Castro Ramos M, Samper S, Otal I, Martin C, Romano MI (1999) Molecular characterization of mycobacteria isolated from seals. Microbiology 145(Pt 9):2519 2526

47. Kamerbeek J, Schouls L, Kolk A, van Agterveld M, van Soolingen D, Kuijper S, Bunschoten A, Molhuizen H, Shaw R, Goyal M, van Embden J (1997) Simultaneous detection and strain differentiation of Mycobacterium tuberculosis for diagnosis and epidemiology. J Clin Microbiol 35(4):907-914

48. Frothingham R, Strickland PL, Bretzel G, Ramaswamy S, Musser JM, Williams DL (1999) Phenotypic and genotypic characterization of Mycobacterium africanum isolates from West Africa. J Clin Microbiol 37(6):1921-1926

49. Filliol I, Motiwala AS, Cavatore M, Qi W, Hazbón MH, Bobadilla del Valle M, Fyfe J, García-García L, Rastogi N, Sola C, Zozio T, Guerrero MI, León CI, Crabtree J, Angiuoli S, Eisenach KD, Durmaz R, Joloba ML, Rendón A, Sifuentes-Osornio J, Ponce de León A, Cave MD, Fleischmann R, Whittam TS, Alland D (2006) Global phylogeny of Mycobacterium tuberculosis based on single nucleotide polymorphism (SNP) analysis: insights into tuberculosis evolution, phylogenetic accuracy of other DNA fingerprinting systems, and recommendations for a minimal standard SNP set. J Bacteriol 188(2):759-772

50. Comas I, Coscolla M, Luo T, Borrell S, Holt KE, Kato-Maeda M, Parkhill J, Malla B, Berg S, Thwaites G, Yeboah-Manu D, Bothamley G, Mei J, Wei L, Bentley S, Harris SR, Niemann S, Diel R, Aseffa A, Gao Q, Young D, Gagneux S (2013) Out-ofAfrica migration and Neolithic coexpansion of Mycobacterium tuberculosis with modern humans. Nat Genet 45(10):1176-1182

51. Reed MB, Pichler VK, McIntosh F, Mattia A, Fallow A, Masala S, Domenech P, Zwerling A, Thibert L, Menzies D, Schwartzman K, Behr MA (2009) Major Mycobacterium tuberculosis lineages associate with patient country of origin. J Clin Microbiol 47(4): $1119-1128$

52. Galagan JE (2014) Genomic insights into tuberculosis. Nat Rev Genet 15(5):307-320
53. Firdessa R, Berg S, Hailu E, Schelling E, Gumi B, Erenso G, Gadisa E, Kiros T, Habtamu M, Hussein J, Zinsstag J, Robertson BD, Ameni G, Lohan AJ, Loftus B, Comas I, Gagneux S, Tschopp R, Yamuah L, Hewinson G, Gordon SV, Young DB, Aseffa A (2013) Mycobacterial lineages causing pulmonary and extrapulmonary tuberculosis, Ethiopia. Emerg Infect Dis 19(3):460-463

54. Monot M, Honoré N, Garnier T, Araoz R, Coppée JY, Lacroix C, Sow S, Spencer JS, Truman RW, Williams DL, Gelber R, Virmond M, Flageul B, Cho SN, Ji B, Paniz-Mondolfi A, Convit J, Young S, Fine PE, Rasolofo V, Brennan PJ, Cole ST (2005) On the origin of leprosy. Science 308(5724):1040-1042

55. Monot M, Honoré N, Garnier T, Zidane N, Sherafi D, PanizMondolfi A, Matsuoka M, Taylor GM, Donoghue HD, Bouwman A, Mays S, Watson C, Lockwood D, Khamesipour A, Dowlati Y, Jianping S, Rea TH, Vera-Cabrera L, Stefani MM, Banu S, Macdonald M, Sapkota BR, Spencer JS, Thomas J, Harshman K, Singh P, Busso P, Gattiker A, Rougemont J, Brennan PJ, Cole ST (2009) Comparative genomic and phylogeographic analysis of Mycobacterium leprae. Nat Genet 41(12): $1282-1289$

56. Matsuoka M, Maeda S, Kai M, Nakata N, Chae GT, Gillis TP, Kobayashi K, Izumi S, Kashiwabara Y (2000) Mycobacterium leprae typing by genomic diversity and global distribution of genotypes. Int J Lepr Other Mycobact Dis 68(2):121-128

57. Shin YC, Lee H, Lee H, Walsh GP, Kim JD, Cho SN (2000) Variable numbers of TTC repeats in Mycobacterium leprae DNA from leprosy patients and use in strain differentiation. $\mathrm{J}$ Clin Microbiol 38(12):4535-4538

58. Groathouse NA, Rivoire B, Kim H, Lee H, Cho SN, Brennan PJ, Vissa VD (2004) Multiple polymorphic loci for molecular typing of strains of Mycobacterium leprae. J Clin Microbiol 42(4):16661672

59. Haas CJ, Zink A, Molńar E, Szeimies U, Reischl U, Marcsik A, Ardagna Y, Dutour O, Pálfi G, Nerlich AG (2000) Molecular evidence for different stages of tuberculosis in ancient bone samples from Hungary. Am J Phys Anthropol 113(3):293-304

60. Mays S, Taylor GM, Legge AJ, Young DB, Turner-Walker G (2001) Paleopathological and biomolecular study of tuberculosis in a medieval skeletal collection from England. Am J Phys Anthropol 114(4):298-311

61. Zink AR, Sola C, Reischl U, Grabner W, Rastogi N, Wolf H, Nerlich AG (2003) Characterization of Mycobacterium tuberculosis complex DNAs from Egyptian mummies by spoligotyping. J Clin Microbiol 41(1):359-367

62. Zink AR, Grabner W, Reischl U, Wolf H, Nerlich AG (2003) Molecular study on human tuberculosis in three geographically distinct and time delineated populations from ancient Egypt. Epidemiol Infect 130(2):239-249

63. Zink AR, Molnár E, Motamedi N, Pálfy G, Marcsik A, Nerlich AG (2007) Molecular history of tuberculosis from ancient mummies and skeletons. Int J Osteoarchaeol 17(4):380-391

64. Fletcher HA, Donoghue HD, Holton J, Pap I, Spigelman M (2003) Widespread occurrence of Mycobacterium tuberculosis DNA from 18th-19th century Hungarians. Am J Phys Anthropol 120(2):144-152

65. Fletcher HA, Donoghue HD, Taylor GM, van der Zanden AG, Spigelman M (2003) Molecular analysis of Mycobacterium tuberculosis DNA from a family of 18th century Hungarians. Microbiology 149(Pt 1):143-151

66. Kay GL, Sergeant MJ, Zhou Z, Chan JZM, Millard A, Quick J, Szikossy I, Pap I, Spigelman M, Loman NJ, Achtman M, Donoghue HD, Pallen MJ (2015) Eighteenth-century genomes show that mixed infections were common at time of peak tuberculosis in Europe. Nat Commun 6:6717. doi:10.1038/ ncomms 7717 
67. Mays S, Taylor GM (2003) A first prehistoric case of tuberculosis from Britain. Int J Osteoarchaeol 13(4):189-196

68. Bachmann L, Däubl B, Lindqvist C, Kruckenhauser L, TeschlerNicola M, Haring E (2008) PCR diagnostics of Mycobacterium tuberculosis in historic human long bone remains from 18th century burials in Kaiserebersdorf, Austria. BMC Res Notes 1:83

69. Müller R, Roberts CA, Brown TA (2014) Biomolecular identification of ancient Mycobacterium tuberculosis complex DNA in human remains from Britain and continental Europe. Am J Phys Anthropol 153(2):178-189

70. Müller R, Roberts CA, Brown TA (2014) Genotyping of ancient Mycobacterium tuberculosis strains reveals historic genetic diversity. Proc Biol Sci 281(1781):20133236

71. Taylor GM, Murphy E, Hopkins R, Rutland P, Chistov Y (2007) First report of Mycobacterium bovis DNA in human remains from the Iron Age. Microbiology 153(Pt 4):1243-1249

72. Bos KI, Harkins KM, Herbig A, Coscolla M, Weber N, Comas I, Forrest SA, Bryant JM, Harris SR, Schuenemann VJ, Campbell TJ, Majander K, Wilbur AK, Guichon RA, Wolfe Steadman DL, Cook DC, Niemann S, Behr MA, Zumarraga M, Bastida R, Huson D, Nieselt K, Young D, Parkhill J, Buikstra JE, Gagneux S, Stone AC, Krause J (2014) Pre-Columbian mycobacterial genomes reveal seals as a source of New World human tuberculosis. Nature 514(7523):494-497

73. Spigelman M, Donoghue HD (2001) Brief communication: unusual pathological condition in the lower extremities of a skeleton from ancient Israel. Am J Phys Anthropol 114(1):92-93

74. Haas CJ, Zink A, Pálfi G, Szeimies U, Nerlich AG (2000) Detection of leprosy in ancient human skeletal remains by molecular identification of Mycobacterium leprae. Am J Clin Pathol 114(3):428-436

75. Donoghue HD, Gładykowska-Rzeczycka J, Marscik A, Holton J, Spigelman M (2002) Mycobacterium leprae in archaeological samples. Archaeopress, Oxford, p 311

76. Taylor GM, Widdison S, Brown IN, Young D, Molleson T (2000) A mediaeval case of lepromatous leprosy from 13-14th century Orkney, Scotland. J Archaeol Sci 27(12):1133-1138

77. Taylor GM, Watson CL, Bouwman AS, Lockwood DNJ, Mays SA (2006) Variable nucleotide tandem repeat (VNTR) typing of two palaeopathological cases of lepromatous leprosy from Mediaeval England. J Archaeol Sci 33(11):1569-1579

78. Watson CL, Lockwood DN (2009) Single nucleotide polymorphism analysis of European archaeological M. leprae DNA. PLoS One 4(10):e7547

79. Watson CL, Popescu E, Boldsen J, Slaus M, Lockwood DN (2010) Correction: Single nucleotide polymorphism analysis of European archaeological M. leprae DNA. PLoS One 5(1)

80. Taylor GM, Donoghue HD (2011) Multiple loci variable number tandem repeat (VNTR) analysis (MLVA) of Mycobacterium leprae isolates amplified from European archaeological human remains with lepromatous leprosy. Microbes Infect 13:923-929

81. Rubini M, Erdal YS, Spigelman M, Zaio P, Donoghue HD (2014) Paleopathological and molecular study on two cases of ancient childhood leprosy from the Roman and Byzantine Empires. Int $\mathbf{J}$ Osteoarchaeol 24:570-582

82. Nuorala E, Donoghue H, Spigelman M, Goterstrom A, Harding Bea (2004) Diet and disease in Björned, a Viking-Early Medieval site in Northern Sweden. Paper II, molecular palaeopathology. Ancient DNA analyses of the bacterial diseases tuberculosis and leprosy. Theses and papers in scientific archaeology, vol. 6. Archaeological Research Laboratory, Stockholm University, Stockholm

83. Economou C, Kjellström A, Lidén K, Panagopoulos I (2013) Ancient-DNA reveals an Asian type of Mycobacterium leprae in medieval Scandinavia. J Archaeol Sci 40(1):465-470
84. Taylor GM, Tucker K, Butler R, Pike AW, Lewis J, Roffey S, Marter P, Lee OY, Wu HH, Minnikin DE, Besra GS, Singh P, Cole ST, Stewart GR (2013) Detection and strain typing of ancient Mycobacterium leprae from a medieval leprosy hospital. PLoS One 8(4):e62406

85. Mendum TA, Schuenemann VJ, Roffey S, Taylor GM, Wu H, Singh P, Tucker K, Hinds J, Cole ST, Kierzek AM, Nieselt K, Krause J, Stewart GR (2014) Mycobacterium leprae genomes from a British medieval leprosy hospital: towards understanding an ancient epidemic. BMC Genomics 15:270

86. Inskip SA, Taylor GM, Zakrzewski SR, Mays SA, Pike AW, Llewellyn G, Williams CM, Lee OY, Wu HH, Minnikin DE, Besra GS, Stewart GR (2015) Osteological, biomolecular and geochemical examination of an early anglo-saxon case of lepromatous leprosy. PLoS One 10(5):e0124282

87. Möller M, Hoal EG (2010) Current findings, challenges and novel approaches in human genetic susceptibility to tuberculosis. Tuberculosis (Edinb) 90(2):71-83

88. Spigelman M, Donoghue HD, Abdeen Z, Ereqat S, Sarie I, Greenblatt CL, Pap I, Szikossy I, Hershkovitz I, Bar-Gal GK, Matheson C (2015) Evolutionary changes in the genome of Mycobacterium tuberculosis and the human genome from 9000 years BP until modern times. Tuberculosis (Edinb). doi:10.1016/j. tube.2015.02.022

89. Hoal EG (2002) Human genetic susceptibility to tuberculosis and other mycobacterial diseases. IUBMB Life 53(4-5):225-229

90. Bellamy R (2005) Genetic susceptibility to tuberculosis. Clin Chest Med 26(2):233-246

91. Azad AK, Sadee W, Schlesinger LS (2012) Innate immune gene polymorphisms in tuberculosis. Infect Immun 80(10):3343-3359

92. Li X, Yang Y, Zhou F, Zhang Y, Lu H, Jin Q, Gao L (2011) SLC11A1 (NRAMP1) polymorphisms and tuberculosis susceptibility: updated systematic review and meta-analysis. PLoS One 6(1):e15831

93. Gruenheid S, Pinner E, Desjardins M, Gros P (1997) Natural resistance to infection with intracellular pathogens: the Nramp1 protein is recruited to the membrane of the phagosome. J Exp Med 185(4):717-730

94. Yen JH, Moore BE, Nakajima T, Scholl D, Schaid DJ, Weyand CM, Goronzy JJ (2001) Major histocompatibility complex class Irecognizing receptors are disease risk genes in rheumatoid arthritis. J Exp Med 193(10):1159-1167

95. Mahfouz R, Halas H, Hoteit R, Saadeh M, Shamseddeen W, Charafeddine K, Itani L, Araj GF (2011) Study of KIR genes in Lebanese patients with tuberculosis. Int J Tuberc Lung Dis 15(12): $1688-1691$

96. Lu C, Bai XL, Shen YJ, Deng YF, Wang CY, Fan G, Chu JX, Zhao SM, Zhang BC, Zhao YR, Zhang CZ, Ye H, Lu ZM (2012) Potential implication of activating killer cell immunoglobulin-like receptor and HLA in onset of pulmonary tuberculosis. Scand J Immunol 76(5):491-496

97. Barnes I, Duda A, Pybus OG, Thomas MG (2011) Ancient urbanization predicts genetic resistance to tuberculosis. Evolution 65(3): 842-848

98. Kołodziejczak-Przekwas M (2012) Alleles protecting against infectious diseases in historical populations. Ph.D. dissertation, Department of Molecular Biology, Medical University of Łodz, Łódź

99. Prado Montes de Oca E (2011) Human polymorphisms as clinical predictors in leprosy. J Trop Med 2011:923943

100. Ahmad S (2011) Pathogenesis, immunology, and diagnosis of latent Mycobacterium tuberculosis infection. Clin Dev Immunol 2011:814943

101. Mira MT, Alcaïs A, Van Thuc N, Moraes MO, Di Flumeri C, Thai VH, Phuong MC, Huong NT, Ba NN, Khoa PX, Sarno EN, Alter A, Montpetit A, Moraes ME, Moraes JR, Doré C, Gallant CJ, 
Lepage P, Verner A, van de Vosse E, Hudson TJ, Abel L, Schurr E (2004) Susceptibility to leprosy is associated with PARK2 and PACRG. Nature 427(6975):636-640

102. Mira MT, Alcaïs A, Van Thuc N, Thai VH, Huong NT, Ba NN, Verner A, Hudson TJ, Abel L, Schurr E (2003) Chromosome 6q25 is linked to susceptibility to leprosy in a Vietnamese population. Nat Genet 33(3):412-415

103. Bakija-Konsuo A, Mulić R, Boraska V, Pehlic M, Huffman JE, Hayward C, Marlais M, Zemunik T, Rudan I (2011) Leprosy epidemics during history increased protective allele frequency of PARK2/PACRG genes in the population of the Mljet Island, Croatia. Eur J Med Genet 54(6):e548-e552

104. Witas HW, Zawicki P (2006) Allele protecting against HIV (CCR5- $\Delta 32$ ) identified in early medieval specimens from Central Poland. Preliminary results. Prz Antropol Anthropol Rev 69:49-53

105. Zawicki P, Witas HW (2008) HIV-1 protecting CCR5-Delta32 allele in medieval Poland. Infect Genet Evol 8(2):146-151
106. Blanpain C, Libert F, Vassart G, Parmentier M (2002) CCR5 and HIV infection. Recept Channels 8(1):19-31

107. Libert F, Cochaux P, Beckman G, Samson M, Aksenova M, Cao A, Czeizel A, Claustres M, de La Rúa C, Ferrari M, Ferrec C, Glover G, Grinde B, Güran S, Kucinskas V, Lavinha J, Mercier B, Ogur G, Peltonen L, Rosatelli C, Schwartz M, Spitsyn V, Timar L, Beckman L, Parmentier M, Vassart G (1998) The $\Delta$ CCR5 mutation conferring protection against HIV-1 in Caucasian populations has a single and recent origin in Northeastern Europe. Hum Mol Genet 7(3):399-406

108. Jagodzinski PP, Lecybył R, Ignacak M, Juszczyk J, Trzeciak WH (2000) Distribution of $\Delta 32$ alelle of the CCR5 gene in the population of Poland. J Hum Genet 45(5):271-274

109. Fontecchio G, Fioroni MA, Azzarone R, Battistoni C, Cervelli C, Ventura L, Mercurio C, Fornaciari G, Papola F (2007) Genetic predisposition to rheumatoid arthritis in a Tuscan (Italy) ancient human remain. Int J Immunopathol Pharmacol 20(1):103-109 